Diskursus: Jurnal Pendidikan Bahasa Indonesia

Vol. 4, No. 1, April 2021, pp. 98-106

p-ISSN: $2615-4935$

e-ISSN: 2615-4943

\title{
Pengaruh Persepsi Kompetensi Pedagogik Guru dan Motivasi Belajar terhadap Prestasi Belajar Bahasa Indonesia
}

\author{
Wikurnia ${ }^{1)}$ \\ Universitas Indraprasta PGRI Jakarta \\ Jalan Nangka No. 58 C/TB. Simatupang, Tanjung Barat,Jakarta Selatan 12530 \\ Sumaryoto ${ }^{2)}$ \\ Universitas Indraprasta PGRI Jakarta \\ Jalan Nangka No. 58 C/TB. Simatupang, Tanjung Barat,Jakarta Selatan 12530 \\ Hasbullah ${ }^{3)}$ \\ Universitas Indraprasta PGRI Jakarta \\ Jalan Nangka No. 58 C/TB. Simatupang, Tanjung Barat,Jakarta Selatan 12530 \\ wikurnia9@gmail.com ${ }^{1)}$
}

\begin{abstract}
The research aims to determine. 1) the influence of perceptions of teacher pedagogic competence and learning motivation together on the Indonesian language learning achievement of students of State Vocational School in Bekasi Regency, 2) the influence of perceptions of teacher pedagogic competence on the Indonesian language learning achievement of students of State Vocational Schools in Bekasi Regency, and 3) the influence of learning motivation on the Indonesian language learning achievement of students of State Vocational Schools in Bekast Regency. This research was conducted using a quantitative approach with the surreal method. The research population consisted of 827 students of State Vocational Schools in Bekasi Regency. The research sample consisted of 89 students. The sampling technique was random. The data analysis technique used in this study is multiple regression analysis. The results of hypothesis testing, the following conclusions are obtained, 1) There is a significant influence of perceptions of teacher pedagogical competence and learning motivation together on the Indonesian language learning achievement of students of State Vocational School in Bekast Regency. This is evidenced by the value of Sig $=0.000<0.05$ and $\boldsymbol{F}_{\text {count }}=42.828$. 2) There is significant influence of perceptions of teacher pedagogical competence about Indonesian language learning achievement for students of State Vocational Schools in Bekasi Regency. This is evidenced by the value of Sig $=0.000<0.05$ and $\boldsymbol{t}_{\text {count }}=8,118$. 3) There is significant influence of learning motivation about Indonesian language learning achievement for students of State Vocational Schools in Bekasi Regency. This is evidenced by the value of Sig = 0.047. $<0.05$ and $\boldsymbol{t}_{\text {count }}=2.018$. The results of this study are useful for improving the results of Indonesian language learning achievement of State Vocational School in Bekasi Regency.
\end{abstract}

Keywords: Perceptions of Teacher Pedagogical Competence, Learning Motivation, and Indonesian Learning Achievement

\begin{abstract}
Abstrak
Penelitian bertujuan untuk mengetahui: 1) pengaruh persepsi kompetensi pedagogik guru dan motivasi belajar secara bersama-sama terhadap prestasi belajar bahasa Indonesia siswa SMK Negeri di Kabupaten Bekasi, 2) pengaruh persepsi kompetensi pedagogik guru terhadap prestasi belajar bahasa Indonesia siswa SMK Negeri di Kabupaten Bekasi, dan 3) pengaruh motivasi belajar terhadap prestasi belajar bahasa Indonesia siswa SMK Negeri di Kabupaten Bekasi. Penelitian ini dilakukan dengan pendekatan kuantitatif dengan metode survei. Populasi penelitian yaitu siswa
\end{abstract}


SMK Negeri di Kabupaten Bekasi dengan jumlah 827 siswa. Sampel penelitian yaitu dengan jumlah 89 siswa. Teknik pengambilan sampel secara acak. Teknik analisis data yang digunakan dalam penelitian ini adalah analisis regresi berganda. Hasil pengujian hipotesis diperoleh simpulan sebagai berikut: 1) Terdapat pengaruh yang signifikan persepsi kompetensi pedagogik guru dan motivasi belajar secara bersama-sama terhadap prestasi belajar bahasa Indonesia siswa SMK Negeri di Kabupaten Bekasi. Hal ini dibuktikan dengan nilai $\mathbf{S i g}=0,000<0,05$ dan $\mathbf{F}_{\text {hitung }}=42,828$. 2) Terdapat pengaruh yang signifikan persepsi kompetensi pedagogik guru terhadap prestasi belajar bahasa Indonesia siswa SMK Negeri di Kabupaten Bekasi. Hal ini dibuktikan dengan nilai Sig = $0,000<0,05$ dan $\mathbf{t}_{\text {hitung }}=8,118$. 3) Terdapat pengaruh yang signifikan motivasi belajar terhadap prestasi belajar bahasa Indonesia siswa SMK Negeri di Kabupaten Bekasi. Hal ini dibuktikan dengan nilai $\mathbf{S i g}=0,047<0,05$ dan $\mathbf{t}_{\text {hitung }}=2,018$. Hasil penelitian ini berguna untuk meningkatkan hasil prestasi belajar bahasa Indonesia di tingkat SMK Negeri di Kabupaten Bekasi.

Kata Kunci: Persepsi Kompetensi Pedagogik Guru, Motivasi Belajar, dan Prestasi Belajar Bahasa Indonesia

\section{PENDAHULUAN}

Dalam dunia kependidikan, permasalahan yang berkenaan dengan profesi guru menjadi salah satu pokok bahasan yang begitu luas dan kompleks. Tidak semua orang dapat dikategorikan sebagai pendidik atau guru, karena guru harus memiliki beberapa persyaratan yang dipenuhi oleh setiap calon pendidik atau guru sebagaimana yang telah ditetapkan dalam Undang-Undang Sistem Pendidikan Nasional, bahwa untuk dapat diangkat sebagai tenaga pengajar, tenaga pendidik yang bersangkutan harus memiliki kualifikasi minimum dan sertifikasi sesuai dengan jenjang kewenangan mengajar sehat jasmani dan rohani, serta memiliki kemampuan untuk mewujudkan tujuan pendidikan nasional.

Proses pembelajaran akan berhasil jika guru harus memiliki kompetensi pedagogik agar bisa membangkitkan motivasi belajar siswa dalam mencapai prestasi belajar yang baik. Untuk memperoleh hasil yang maksimal, seorang guru dituntut untuk dapat kreatif dalam membangun motivasi belajar siswa. Sehingga terciptalah bentuk motivasi belajar siswa yang efektif. Bahkan ada pula pendidik yang tidak mengetahui bagaimana supaya anak didiknya mendapatkan prestasi yang memuaskan. Hanya mengajar di kelas tanpa mengetahui seperti apa keadaan anak didik, baik psikologis maupun fisiknya.

Kompetensi guru merupakan kemampuan dan kewenangan seorang guru dalam melaksanakan kewajiban-kewajibannya secara bertanggung jawab terkait dengan profesi keguruannya. Karena jabatan guru merupakan pekerjaan profesi, maka kompetensi guru sangatlah dibutuhkan dalam proses belajar mengajar. Dalam kaitannya dengan pendidikan, kompetensi menunjukkan kepada perbuatan yang bersifat rasional untuk mencapai suatu tujuan yang sesuai dengan kondisi yang diharapkan. Kompetensi ini diperoleh melalui proses pendidikan atau latihan. Menurut Darmadi (2010), menyebutkan ada empat kompetensi guru, yaitu: kompetensi pedagogik, kompetensi kepribadian, kompetensi pedagogik dan kompetensi sosial. Kompetensi yang paling utama harus dimiliki guru agar pembelajaran menjadi efektif dan dinamis adalah kompetensi pedagogik.

Menurut Simamora (2014:26), persepsi siswa tentang kompetensi pedagogik guru adalah proses dimana siswa menjadi sadar didalam lingkungan belajarnya melalui interprestasi data indera yang dimiliki untuk memberikan 
gambaran atas kecakapan dan kesiapan guru dalam menyelenggarakan pembelajarannya.

Persepsi siswa atas kompetensi pedagogik guru akan terlihat dalam proses belajar, karena guru yang memiliki kompetensi pedagodik kegiatan pembelajaran akan berjalan dengan baik dan bisa menghasilkan motivasi belajar siswa sehingga siswa mendapatkan prestasi belajar yang baik. Sebaliknya, jika guru tidak memiliki kompetensi pedagogik akan terlihat kegiatan pembelajaran akan membosan dan tidak akan menumbuhkan motivasi belajar siswa.

Menurut Dimyati dan Mudjiono (2015:239) Motivasi belajar merupakan kekuatan mental yang mendorong terjadinya proses belajar. Motivasi belajar yang kuat akan menumbuhkan gairah, merasa senang dan semangat untuk belajar sehingga tercapai suatu hasil yang maksimal. Dengan adanya motivasi yang kuat dan bersifat positif, siswa akan bersemangat dalam menjalankan tugasnya agar dapat meraih prestasi belajar yang lebih baik. Sedangkan menurut Retariandalas (2017:191) Siswa tergerak untuk mau belajar karena didorong oleh suatu motivasi. Motivasi dapat diperoleh dari dalam diri siswa juga dari luar diri siswa. Motivasi orangtua dan motivasi guru adalah contoh yang berasal dari luar diri siswa. Sedangkan motivasi yang berasal dari dalam diri siswa yaitu motivasi diri dan motivasi belajar. Motivasi diri inilah yang sangat minim dimiliki oleh siswa. Siswa hanya bergantung dari motivasi orangtua atau guru sehingga jika mereka tidak mendapatkannya maka tidak akan ada faktor penggerak mereka untuk belajar.

Prestasi belajar adalah serangkaian kalimat yang terdiri dari dua kata yaitu, prestasi dan belajar. Keduanya mempunyai pengertian atau makna yang berbeda. Menurut Djamarah (2000:19) prestasi adalah hasil dari suatu kegiatan yang telah dikerjakan, diciptakan, baik secara individu maupun kelompok. Prestasi tidak mungkin dicapai atau dihasilkan oleh seseorang selama ia tidak melakukan kegiatan dengan sungguh-sungguh atau dengan perjuangan yang gigih. Sedangkan pengertian belajar adalah rangkaian kegiatan jiwa-raga, psiko-fisik menuju ke perkembangan pribadi manusia seutuhnya, yang menyangkut unsur cipta, rasa dan karsa, ranah kognitif, afektif dan psikomotorik (Sardiman, 2007).

Menurut Simamora (2014:24), Prestasi Belajar adalah suatu penilaian akhir dari proses dan pengenalan yang telah dilakukan berulangulang, serta akan tersimpan dalam jangka waktu lama atau bahkan tidak akan hilang selama-lamanya. Oleh karena itu Prestasi Belajar turut serta dalam membentuk pribadi individu yang selalu ingin mencapai hasil yang lebih baik lagi sehingga akan merubah cara berpikir serta menghasilkan perilaku yang lebih baik.

Dengan kompetensi pegagogik guru yang baik dapat membuat motivasi belajar siswa menjadi baik dan begitu pula sebaliknya. Maka dalam proses belajar pemerolehan prestasi belajar yang baik dipengaruhi dari kompetensi pedagogik guru yang membangkitkan motivasi belajar siswa.

Berdasarkan uraian di atas, pokok masalah yang diteliti dirumuskan dalam pertanyaan sebagai berikut: 1) Apakah terdapat pengaruh persepsi kompetensi pedagogik guru dan motivasi belajar secara bersama-sama terhadap prestasi belajar bahasa Indonesia siswa SMK Negeri di Kabupaten Bekasi? 2) Apakah terdapat pengaruh persepsi kompetensi pedagogik guru terhadap prestasi belajar bahasa Indonesia siswa SMK Negeri di Kabupaten Bekasi? 3) Apakah terdapat pengaruh 
motivasi belajar terhadap prestasi belajar bahasa Indonesia siswa SMK Negeri di Kabupaten Bekasi?

Tujuan penelitian ini adalah untuk mengetahui: 1) Pengaruh persepsi kompetensi pedagogik guru dan motivasi belajar secara bersama-sama terhadap prestasi belajar bahasa Indonesia siswa SMK Negeri di Kabupaten Bekasi 2) Pengaruh persepsi kompetensi pedagogik guru terhadap prestasi belajar bahasa Indonesia siswa SMK Negeri di Kabupaten Bekasi 3) Pengaruh motivasi belajar terhadap prestasi belajar bahasa Indonesia siswa SMK Negeri di Kabupaten Bekasi.

\section{METODE}

Metode dalam penelitian ini menggunakan metode survey dengan tehnik analisis korelasional dan regresi dengan pendekatan kuantitatif, yaitu mencari hubungan dan pengaruh antara dua variabel bebas dengan satu variabel terikat berdasarkan analisis regresi linier berganda. Variabel-variabel yang diteliti yaitu persepsi kompetensi pedagogik guru $\left(\mathrm{X}_{1}\right)$, motivasi belajar $\left(\mathrm{X}_{2}\right)$ dan prestasi belajar bahasa Indonesia (Y). Teknik yang digunakan dalam pengumpulan data yaitu variabel persepsi kompetensi pedagogik guru $\left(\mathrm{X}_{1}\right)$ dan motivasi belajar $\left(\mathrm{X}_{2}\right)$ menggunakan angket, sedangkan variabel prestasi belajar bahasa Indonesia (Y) dari hasil penilaian tengah semester. Data dikumpulkan berdasarkan angket (kuisioner) yang dikembangkan peneliti dan diberikan kepada sampel dari populasi dengan jumlah 827 dan sampel penelitian berjumlah 89 orang, yang diambil dengan teknik random sampling dari dua sekolah. Sampel penelitian dari SMK Negeri 1 Cikarang Selatan berjumlah 50 siswa dan SMK Negeri 1 Cikarang Pusat berjumlah 39 siswa di kabupaten Bekasi. berikut:

Hubungan antara ketiga variabel tersebut dapat digambarkan sebagai

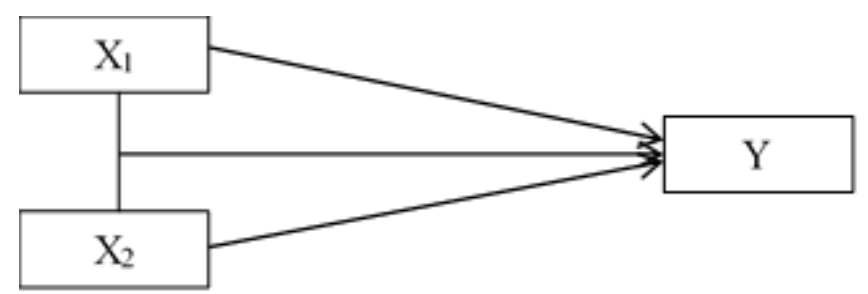

\section{Gambar 1: Hubungan Antara Variabel}

Keterangan:

$\mathrm{X}_{1}=$ persepsi kompetensi pedagogik guru

$\mathrm{X}_{2}=$ motivasi belajar

$\mathrm{Y}=$ prestasi belajar bahasa Indonesia 
Diskursus: Jurnal Pendidikan Bahasa Indonesia

Vol. 4, No. 1, April 2021, pp. 98-106

p-ISSN: $2615-4935$

e-ISSN: 2615-4943

\section{HASIL DAN PEMBAHASAN}

\section{Hasil}

Berdasarkan pengolahan data diperoleh hasil sebagai berikut:

Tabel 1. Hasil Statistik Deskritif

\begin{tabular}{llccc}
\hline \multirow{2}{*}{ No } & \multirow{2}{*}{ Ukuran Deskriptif } & \multicolumn{3}{c}{ Nilai } \\
\cline { 3 - 5 } & & $\mathrm{X} 1$ & $\mathrm{X} 2$ & $\mathrm{Y}$ \\
\hline 1 & Modus & 110 & 117 & 74 \\
2 & Median & 110 & 113 & 76 \\
3 & Mean & 106,83 & 111,24 & 74,54 \\
4 & Standar deviasi & 12,122 & 11,786 & 7,721 \\
5 & Minimun & 88 & 88 & 60 \\
6 & Maksimum & 128 & 134 & 88 \\
\hline
\end{tabular}

Tabel 2. Hasil Perhitungan Koefisian Korelasi Pengaruh Variabel X1 dan X2 Secara Bersama terhadap Variabel Y

\begin{tabular}{ccccc}
\hline Model & R & R Square & Adjusted R Square & $\begin{array}{c}\text { Std. Error of the } \\
\text { Estimate }\end{array}$ \\
\hline 1 & $.706^{\mathrm{a}}$ & .499 & .487 & 5.528 \\
\hline
\end{tabular}

Tabel 3. Hasil Perhitungan Koefisian Korelasi Pengaruh Variabel X1 dan X2 Secara Bersama terhadap Variabel Y

\begin{tabular}{llrrrrr}
\hline \multirow{2}{*}{ Model } & \multicolumn{1}{l}{$\begin{array}{l}\text { Sum of } \\
\text { Squares }\end{array}$} & df & Mean Square & F & Sig. \\
\hline \multirow{2}{*}{1} & Regression & 2617.798 & 2 & 1308.899 & 42.828 & $.000^{\mathrm{b}}$ \\
Residual & 2628.315 & 86 & 30.562 & & \\
\hline & Total & 5246.112 & 88 & & & \\
\hline
\end{tabular}

a. Dependent Variable: Prestasi Belajar Bahasa Indonesia

b. Predictors:(Constant), Motivasi Belajar, Persepsi Kompetensi Pedagogik Guru

Tabel 4. Hasil Perhitungan Persamaan Garis regresi Pengaruh Variabel X1 dan X2 Secara Bersama terhadap Variabel Y.

\begin{tabular}{|c|c|c|c|c|c|c|}
\hline \multirow{2}{*}{\multicolumn{2}{|c|}{ Model }} & \multicolumn{2}{|c|}{$\begin{array}{l}\text { Unstandardized } \\
\text { Coefficients }\end{array}$} & \multirow{2}{*}{$\begin{array}{c}\begin{array}{c}\text { Standardized } \\
\text { Coefficients }\end{array} \\
\text { Beta }\end{array}$} & \multirow[t]{2}{*}{$\mathrm{t}$} & \multirow[t]{2}{*}{ Sig. } \\
\hline & & $\mathrm{B}$ & Std. Error & & & \\
\hline \multirow{5}{*}{1} & (Constant) & 18.973 & 6.761 & & 2.806 & .006 \\
\hline & Persepsi & & & & & \\
\hline & Kompetensi & .411 & .051 & .645 & 8.118 & .000 \\
\hline & Pedagogik Guru & & & & & \\
\hline & $\begin{array}{l}\text { Motivasi } \\
\text { Belajar }\end{array}$ & .105 & .052 & .160 & 2.018 & .047 \\
\hline
\end{tabular}

a. Dependent Variable: Prestasi Belajar Bahasa Indonesia 


\section{Pembahasan}

Dari tabel 1 terlihat bahwa hasil analisis deskriptif setiap variabel antara lain data prestasi belajar bahasa Indonesia siswa yang telah dilakukan dengan menggunakan SPSS 20.0 dengan jumlah responden 89 orang memperoleh hasil rentang nilai frekuensi distributif terletak pada angka minimum dan maksimum 60 \pm 88 . Rentangan ini memberikan gambaran bahwa nilai terendah prestasi belajar bahasa Indonesia adalah 60 yang berarti ada siswa yang menjawab 10 soal salah dari 25 soal yang diberikan. Sedangkan nilai maksimum 88 berarti siswa dapat menjawab 22 dengan benar dari 25 soal. Nilai mean atau rata-rata jawaban responden adalah sebesar 74,54 . Hal ini mengindikasikan bahwa prestasi belajar bahasa Indonesia siswa masuk dalam kategori cukup baik. Sementara itu, nilai tengah (median) dan nilai yang sering muncul (modus) masing-masing adalah sebesar 76,00 dan 74 dengan standar deviasi sebesar 7,721. Data hasil angket persepsi kompetensi pedagogik memperoleh angka minimum dan maksimum $88 \pm$ 128. Nilai mean jawaban responden adalah sebesar 106,83. Hal ini mengindikasikan bahwa siswa rata-rata mempunyai persepsi kompetensi pedagogik yang cukup tinggi. Sementara itu median dan modus masing-masing adalah sebesar 110 dengan standar deviasi sebesar 12,122. Data hasil angket motivasi belajar memperoleh rentang nilai $88 \pm 134$. Nilai mean sebesar 111,24 yang mengindikasikan bahwa rata-rata siswa mempunyai motivasi yang baik. Sementara itu median dan modus masing-masing sebesar 113 dan 117 dengan standar deviasi sebesar 11,786.

\section{Pengaruh Persepsi Kompetensi Pedagogik Guru dan Motivasi belajar secara Bersama-Sama Terhadap Prestasi Belajar Bahasa Indonesia}

Dari tabel 2 terlihat bahwa koefisien korelasi ganda pengaruh variabel bebas persepsi kompetensi pedagogik guru $\left(\mathrm{X}_{1}\right)$ dan motivasi belajar $\left(\mathrm{X}_{2}\right)$ secara bersamasama terhadap prestasi belajar bahasa Indonesia (Y) adalah sebesar 0,706. Perhitungan pengujian signifikansi diperoleh bahwa koefisien korelasi tersebut signifikan, dengan kata lain terdapat pengaruh yang signifikan variabel bebas persepsi kompetensi pedagogik guru $\left(\mathrm{X}_{1}\right)$ dan motivasi belajar $\left(\mathrm{X}_{2}\right)$ secara bersamasama terhadap prestasi belajar bahasa Indonesia (Y). Sedangkan koefisien determinasinya sebesar 49,9\% menunjukkan kontribusi persepsi kompetensi pedagogik guru dan motivasi belajar secara bersama-sama terhadap prestasi belajar bahasa Indonesia sebesar 49,9\%, sisanya 50,1\% karena pengaruh variabel (faktor) lain. Dari tabel 3 diperoleh persamaan garis regresi yang merepresentasikan pengaruh variabel $X_{1}$ dan $X_{2}$ terhadap variabel $Y$, yaitu $=18,973 \pm 0,411 X_{1}+0,105$ $\mathrm{X}_{2}$.

Pada Tabel 1 terlihat bahwa nilai nilai Sig $=0,000$ dan $\mathbf{F}_{\text {hitung }}=42,828$, sedangkan $\mathbf{F}_{\text {tabel }}=3,09$. Karena nilai Sig $<0,05$ dan $\mathbf{F}_{\text {hitung }}>\mathbf{F}_{\text {tabel }}$ maka $\mathrm{H}_{0}$ ditolak yang berarti bahwa koefisien regresi tersebut signifikan. Berarti bahwa terdapat pengaruh signifikan variabel bebas persepsi kompetensi pedagogik guru $\left(\mathrm{X}_{1}\right)$ dan motivasi belajar siswa $\left(\mathrm{X}_{2}\right)$ secara bersama-sama terhadap prestasi belajar bahasa Indonesia (Y). Dari pengujian korelasi dan regresi tersebut maka dapat disimpulkan bahwa terdapat pengaruh persepsi kompetensi pedagogik guru $\left(\mathrm{X}_{1}\right)$ dan motivasi 
belajar siswa $\left(\mathrm{X}_{2}\right)$ secara bersama-sama terhadap prestasi belajar bahasa Indonesia (Y).

Proses belajar atau prestasi belajar dipengaruhi dua faktor yaitu faktor intern dan faktor ekstern. Faktor intern yaitu faktor jasmaniah dan faktor psikologis. Faktor jasmani berupa keadaaan kesehatan dan cacat tubuh pada siswa. Sedangkan faktor psikologis berupa intelegensi, perhatian, minat, bakat, motif, dan kesiapan siswa. Sedangkan faktor ekstern yaitu faktor keluarga, sekolah dan masyarakat. Faktor keluarga berupa cara orang tua mendidik, keadaan ekonomi keluarga dan pengertian orang tua kepada siswa. Faktor sekolah berupa metode mengajar, kurikulum, relasi guru dengan siswam relasi, selasi siswa dengan siswa, disiplin sekolah, metode belajar, dan tugas rumah. Selanjutnya faktor masyarakat berupa kegiatan siswa di masyarakat, media massa, dan bentuk kehidupan masyarakat.

Dari teori tentang prestasi belajar dan hal-hal yang berhubungan dengan persepsi kompetensi pedagogik guru dan motivasi belajar. Persepsi Kompetensi Pedagogik Guru adalah persepsi seseorang pada kompetensi pedagogik yang dimiliki guru dalam proses mengajar/ mendidik siswa. Motivasi belajar adalah dorongan internal dan eksternal, yang mendorong seseorang untuk belajar karena adanya hasrat, kebutuhan, harapan, cita-cita, aktualisasi diri, ketertarikan belajar, lingkungan yang nyaman, serta informasi tentang kekuatan, semangat, usaha, kondisi psikologis, mengarahkan, semangat kejiwaan, kemampuan internet dalam diri seseorang, motor penggerak, arah, perjalanan setelah belajar.hasil belajar bila seseorang telah belajar akan terjadi perubahan tingkah laku pada orang tersebut.

\section{Pengaruh Persepsi Kompetensi Pedagogik Guru terhadap Prestasi Belajar Bahasa Indonesia}

Dari Tabel 4 terlihat bahwa nilai Sig $=0,000$ dan $\mathbf{t}_{\text {hitung }}=8,118$, sedangkan $\mathbf{t}_{\text {tabel }}=1,98$. Karena nilai Sig $>0,05$ dan $\mathbf{t}_{\text {hitung }}>\mathbf{t}_{\text {tabel }}$ maka $\mathrm{H}_{0}$ ditolak yang berarti terdapat pengaruh yang signifikan variabel bebas $\mathrm{X}_{1}$ (persepsi kompetensi pedagogik guru) terhadap variabel terikat Y (prestasi belajar bahasa Indonesia). Dari hasil pengujian korelasi, pengujian regresi maupun dengan melihat model garis tersebut maka dapat disimpulkan bahwa terdapat pengaruh yang signifikan variabel bebas $\mathrm{X}_{1}$ (persepsi kompetensi pedagogik guru) terhadap variabel terikat Y (prestasi belajar bahasa Indonesia).

Persepsi kompetensi guru adalah proses awal dalam mengenali, memahami kompetensi pedagogik yang dimiliki guru dalam melakukan suatu aktivitas kegiatan belajar mengajar, yaitu mendidik, membimbing, dan melatih siswa dalam pembelajaran. yakni dalam hal menguasai karakteristik siswa, menguasai teori belajar dan prinsip-prinsip pembelajaran yang mendidik, mengembangkan kurikulum yang terkait dengan mata pelajaran dengan mata pelajaran yang diampu, menyelenggarakan pembelajaran yang mendidik, memfasilitasi pengembangan potensi siswa, berkomunikasi secara efektif, empatik, dan santun dengan siswa.

Menurut pendapat para ahli, kompetensi pedagogik guru adalah seorang pendidik yang memiliki kemampuan mengelola pembelajaran meliputi, pemahaman terhadap siswa, perancangan dan pelaksanaan pembelajaran, evaluasi hasil belajar, dan pengembangan potensi yang dimiliki siswa. Semakin baik kompetensi pedagogic yang dimiliki guru maka semakin baik proses kegiatan 
belajar siswa, sehingga dapat membangkitkan motivasi belajar siswa agar meraih prestasi belajar bahasa Indonesia yang maksimal.

\section{Pengaruh Motivasi belajar terhadap Prestasi Belajar Bahasa Indonesia}

Pada tabel 4 terlihat bahwa nilai $\mathbf{S i g}=0,047$ dan $\mathbf{t}_{\text {hitung }}=2,018$, sedangkan $\mathbf{t}_{\text {tabel }}=1,98$. Karena nilai Sig $<0,05$ dan $\mathbf{t}_{\text {hitung }}>\mathbf{t}_{\text {tabel }}$ maka $\mathrm{H}_{0}$ ditolak yang berarti terdapat pengaruh yang signifikan variabel bebas $\mathrm{X}_{2}$ (motivasi belajar) terhadap variabel terikat Y (prestasi belajar bahasa Indonesia). Dari hasil pengujian korelasi, pengujian regresi maupun dengan melihat model garis tersebut maka dapat disimpulkan bahwa terdapat pengaruh yang signifikan variabel bebas $\mathrm{X}_{2}$ (motivasi belajar) terhadap variabel terikat Y (prestasi belajar bahasa Indonesia).

Menurut Seno (2020:15) motivasi belajar merupakan dorongan dari dalam diri seseorang atau faktor yang menimbulkan ketertarikan atau perhatian secara selektif yang menyebabkan dipilihnya suatu objek atau kegiatan yaitu menulis sebagai suatu kegiatan yang menguntungkan, menyenangkan atau mendatangkan kepuasan. Hasil analisis hubungan motivasi belajar dengan keterampilan menulis menunjukkan adanya hubungan positif yang signifikan antara kedua variabel. Hal ini dapat diartikan bahwa semakin tinggi motivasi belajar siswa, maka semakin baik pula keterampilan menulisnya. Simpulan tersebut menjelaskan bahwa keterampilan menulis siswa terbukti berkaitan dengan motivasi belajar siswa. Motivasi belajar yang dimiliki siswa akan menjadi pendorong dalam kegiatan belajar, termasuk kegiatan belajar menulis.

Dalam motivasi intrinsik dan motivasi ekstrinsik membutuhkan dorongan dan rangsangan baik dari dalam mapun dari luar individu. Berbagai macam cara bisa dilakukan agar siswa termotivasi dalam belajar. Guru harus bisa membangkitkan motivasi siswa dengan memanfaatkan motivasi ekstrinsik dalam bebagai macam bentuknya. Kesalahan penggunaan bentuk-bentuk motivasi ekstrinsik akan merugikan siswa. Akibatnya motivasi ekstrinsik bukan berfungsi sebagai pedorong, tetapi menjadikan siswa malas belajar sehingga prestasi belajar bahasa Indonesia akan menurun atau buruk,

Dengan adanya motivasi yang kuat dan bersifat positif, siswa akan bersemangat dalam menjalankan tugasnya agar dapat meraih prestasi belajar yang lebih baik. Diharapkan guru dapat meningkatkan motivasi belajar siswa dalam kondisi tertentu yang mementingkan keterlibatan dan keaktifan siswa dalam pembelajaran. Sejauh ini, siswa perlu didorong untuk mampu menata belajarnya sendiri dan menggunakan interaksi antar pribadi dengan teman dan guru untuk mengembangkan kemampuan kognitif, intelektual dan kemampuan sosial. Di samping itu, keterlibatan orang tua dalam belajar siswa perlu diusahakan, baik berupa perhatian dan bimbingan kepada anak di dalam rumah maupun partisipasi secara individu maupun kolektif.

\section{SIMPULAN}

Berdasarkan hasil analisis data dapat disimpulkan bahwa terdapat pengaruh yang signifikan persepsi kompetensi pedagogik guru dan motivasi belajar secara 
bersama-sama terhadap prestasi belajar bahasa Indonesia pada siswa SMK Negeri di Kabupaten Bekasi. Hal ini dibuktikan dengan perolehan nilai Sig $=0,000<0,05$ dan $\mathbf{F}_{\text {hitung }}=42,828$. Terdapat pengaruh yang signifikan persepsi kompetensi pedagogik guru terhadap prestasi belajar bahasa Indonesia pada siswa SMK Negeri di Kabupaten Bekasi. Hal ini dibuktikan dengan perolehan nilai Sig $=0,000<0,05$ dan $\mathbf{t}_{\text {hitung }}=8,118$. Terdapat pengaruh yang signifikan motivasi belajar terhadap prestasi belajar bahasa Indonesia pada siswa SMK Negeri di Kabupaten Bekasi. Hal ini dibuktikan dengan perolehan nilai Sig $=0,047<0,05$ dan $\mathbf{t}_{\text {hitung }}=2,018$. Hasil penelitian menunjukan bahwa guru yang memiliki kompetensi pedagogik yang baik dapat menimbulkan motivasi belajar yang baik sehingga hasil belajar atau prestasi belajar bahasa Indonesia semakin meningkat. Sebaliknya jika guru tidak memiliki kompetensi pedagogi guru yang baik dapat menimbulkan motivasi belajar yang buruk, siswa malas dan dapat menurunkan prestasi belajar bahasa Indonesia

\section{DAFTAR PUSTAKA}

Darmadi, H. (2010). Kemampuan dasar mengajar. Bandung: Alfabeta.

Dimyati., \& Mudjiono. (2015). Belajar dan pembelajaran. Jakarta: Rineka Cipta

Djamarah, S. B. (2000). Prestasi belajar dan kompetensi guru. Surabaya: Usaha Nasional.

Retariandalas. (2017). Pengaruh minat membaca dan motivasi belajar siswa terhadap prestasi belajar IPA. Jurnal Formatif, 7(2): 190-197, 2017..https://www.neliti.com/journals/formatif

Sardiman, A. M. (2007). Interaksi \& motivasi belajar mengajar. Jakarta: PT Raja Grafindo Persada.

Seno, A. J. R. (2020). Pengaruh motivasi belajar dan kemampuan menyimakterhadap keterampilan menulis teks pidato (Survei pada SMA Negeri di Kota Cilegon). Diskursus: Jurnal Pendidikan Bahasa Indonesia Vol. 3, No. 1, April 2020, pp. 55-62. https://journal.lppmunindra.ac.id/index.php/diskursus

Simamora, L. (2014). Pengaruh persepsi siswa tentang kompetensi pedagogik guru dan kebiasaan belajar siswa terhadap prestasi belajar Matematika. Jurnal Formatif, 4(1): 21-30, 2014..https://www.neliti.com/journals/formatif 